\title{
Requalificação Urbanística e Recuperação da Imagem da Cidade O Projeto Rio Cidade para os Bairros do Méier e do Leblon, Rio de Janeiro
}

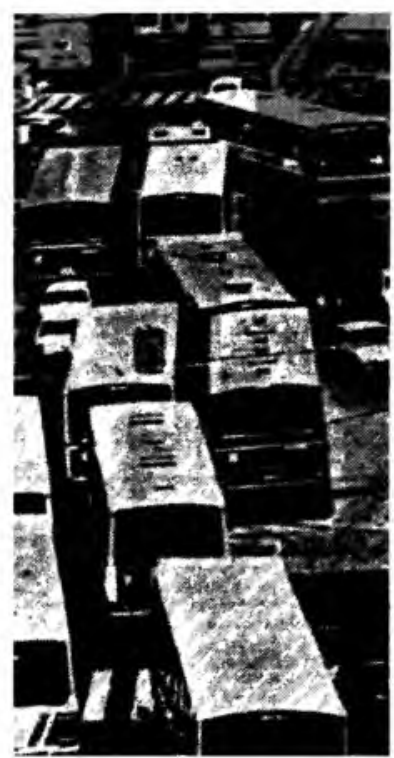

Arquiteto, mestre em desenho urbano (Oxford) e doutor em arquitetura e urbanismo (USP); professor titular (FAU/UFRJ); foi coordenador do

Projeto Rio Cidade na Mayerhofer \& Toledo

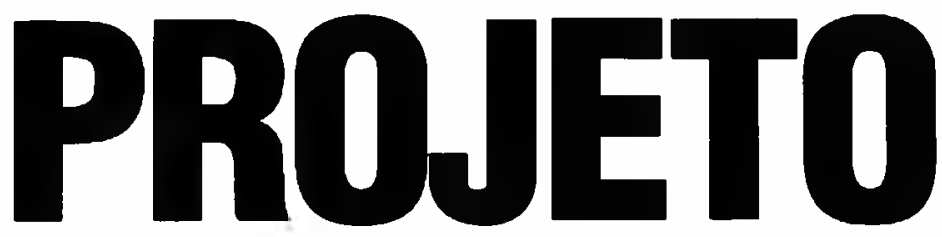


Uma discussão sobre os principais aspectos dos projetos Rio Cidade para o Méier e o Leblon - bairros representativos da zona norte e sul cariocas - é o pano de fundo para esse artigo que aborda o bem sucedido programa de requalificação urbanistica que vem sendo promovido pela Prefeitura do Rio de Janeiro desde 1993 . É apresentado o contexto em que se realizou o concurso para escolha dos primeiros escritórios, a estratégia para recuperação da imagem da cidade, as principais questões conceituais e metodológicas, além de

U. uma avaliação inicial dos resultados atingidos.

A discussion of the main features in the Rio Cidade projects for Meier and Leblon - residential districts that are representative of the north and south zones - is the backdrop for this article that comments on a well-succeeded program for urban renovation that has been promoted by the City since 1993. We introduce the context of the public competition which chose the first design teams, the strategy of the local government to rebuild the image of the city, the main conceptual and methodological questions involved, and an initial evaluation of the results.

m
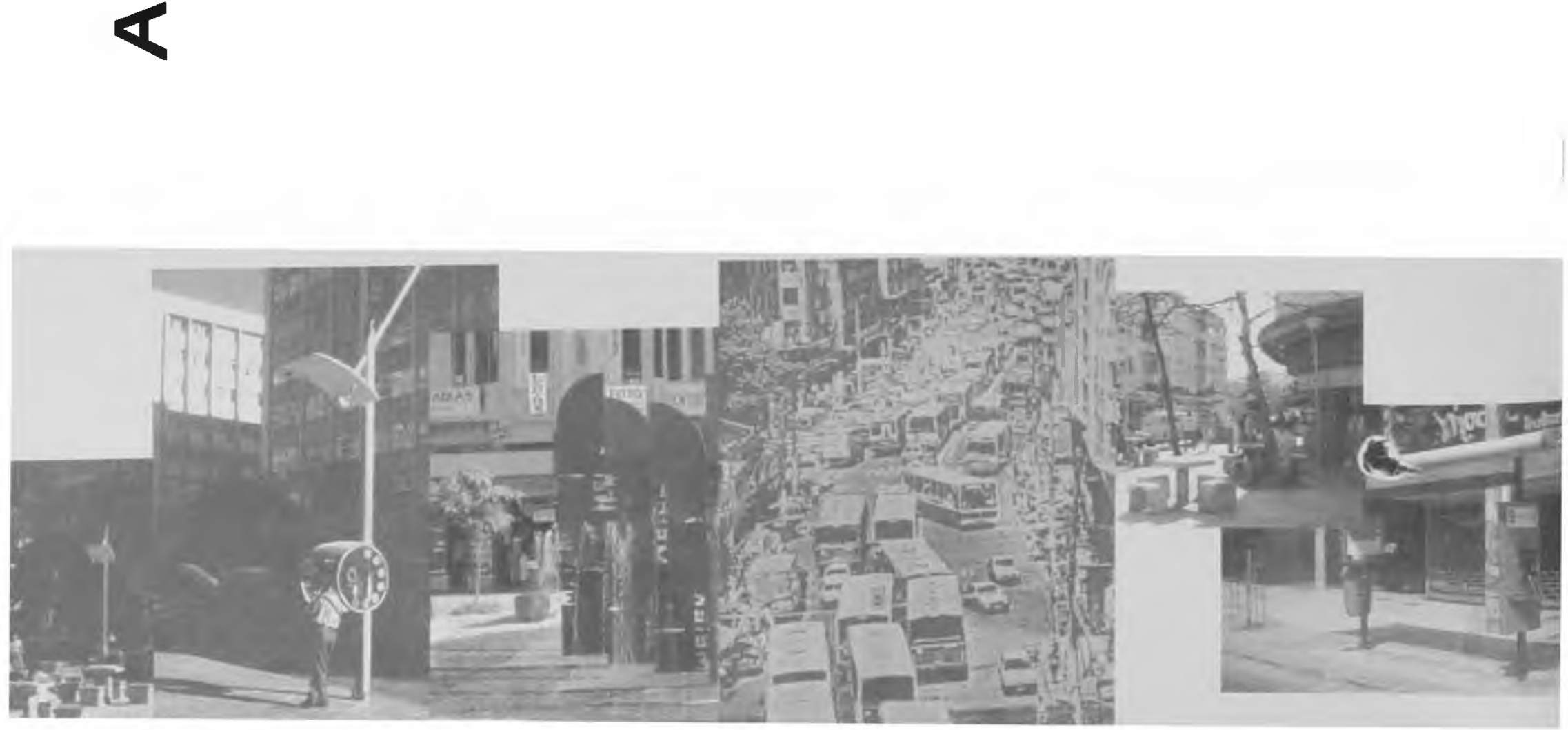


\section{Requalificação Urbanística e Recuperação da Imagem da Cidade O Projeto Rio Cidade para os Bairros do Méier e do Leblon, Rio de Janeiro}

Em fase de implementação pela prefeitura do Rio de Janeiro, o Projeto Rio Cidade é um programa urbanístico que visa recuperar áreas comerciais estratégicas pela requalificação de espaços públicos, tanto em nível funcional quanto no que diz respeito à sua apropriação pelos pedestres. Implementado desde fins de 1993 e envolvendo um total de 46 áreas de intervenção no centro e em diversos bairros das zonas sul, norte e oeste, trata-se de um programa composto por açōes amplas e integradas que incluem o desenho urbano, a circulação viária e a sinalização, o paisagismo e a arborização, a iluminação pública e o mobiliário urbano.

Apesar dos problemas enfrentados, os resultados têm se mostrado extremamente positivos, acarretando significativas melhorias funcionais, aumento do conforto dos pedestres e do senso de identidade nos bairros, além da recuperação da imagem da cidade por seus cidadãos e pela mídia internacional. Neste ensaio, iremos discutir alguns aspectos conceituais e de implantação deste programa, com ênfase especial nos projetos já implantađos no Méier e no Leblon, bairros que representam bem os dois extremos do contexto urbanístico carioca, as zonas norte e sul, respectivamente.

\section{Introdução: Precedentes para o Projeto}

É importante compreender como o Projeto Rio Cidade insere-se historica e politicamente no atual momento de desenvolvimento urbano da cidade. Após a mudança da capital para Brasília e a fusão administrativa com o estado, o Rio de Janeiro começou a viver um longo período de indefinições políticas e esvaziamento financeiro. Acirrada pelo modelo de desenvolvimento do país e pela crise econômica dos anos 80 , essa situação contribuiu para a profunda crise urbanística que se abateu sobre a cidade e cujos resultados são claramente visíveis em sua estrutura espacial e qualidade urbanística'

(1) Para uma ampla compreensão da evolução e estruturação do Rio de Janeiro, vide o clássico trabalho de Maurício Abreu (1987). 
Nos anos 60 e 70 fortaleceu-se o modelo núcleo-periferia de estruturação espacial da cidade e da regiāo metropolitana, que privilegia o centro e alguns poucos bairros, enquanto o restante da malha urbana sofre todos os tipos de necessidades. Por um lado, o paradigma de desenvolvimento fomentava essa situação espacial pelo tipo de crescimento econômico, das políticas públicas de concentração de investimentos, da setorização de açōes, da urbanização seletiva e de simplórias soluções funcionalistas. Os altos investimentos no sistema viário, por exemplo, respondiam à consolidação da indústria automobilística e, no Rio dos anos 60, isso representou uma "febre de construção de viadutos e novas avenidas", na tentativa de adequação do espaço urbano (Abreu, 1987, 133).

Por outro lado, a estratificação da cidade e a especulação imobiliária geraram uma legislação de uso e ocupaçāo do solo de cunho exacerbadamente modernista, baseada em um modelo rígido que ignorava as idiossincrasias dos bairros e praticamente impunha a mesma tipologia arquitetônica por toda a cidade. Os conflitos intensificaram-se a partir do zoneamento e código de obras de 1976, quando o executivo municipal tinha a prerrogativa de legislar matérias urbanísticas por decreto e alterava constantemente as "regras do jogo" urbano em favor de interesses muito específicos ${ }^{2}$ Certamente, muitas outras cidades viram-se em situação semeIhante, mas os conflitos sociais, físicos e espaciais resultantes dos embates políticos e da aplicação dos preceitos modernistas, vigentes no bojo da tecnocracia, foram particularmente impróprios no Rio, cidade privilegiada pelo seu sítio natural, pelo conjunto de seus bairros e pela identidade do seu desenho urbano.

Some-se a isto uma longa lista de governantes municipais pouco interessados na questão da qualidade da dimensão pública da cidade - seja sob a perspectiva social, ambiental ou físicoespacial - o aumento da pobreza e os índices de criminalidade e insegurança, e tem-se a situação que caracterizava o Rio de Janeiro do início dos anos 90 , fazendo com que perdesse o título de "cidade maravilhosa" e passasse a gozar de uma imagem extremamente desgastada nacional e internacionalmente. Mesmo a realização da ECO-92, com o seu par de obras de impacto (Linha Vermelha, via expressa de acesso à cidade e ao aeroporto, e redesenho dos passeios nas praias de Copacabana, Ipanema e Leblon), revelaram-se de conseqüências restritas e a qualidade de vida e do espaço público carioca, de fato, pouco mudariam.

A exceção ficou por conta do pioneirismo e da excelência do Projeto Corredor Cultural, iniciado nos anos 80 e hoje tomado como exemplo de preservação urbana em todo o Brasil. Constituindo, na verdade, um processo especial de gestão urbanística, o projeto abrange significativa área do centro histórico e de negócios, incluindo mais de 1.500 imóveis históricos. Por meio de legislação própria, diretrizes para projeto, isenções tributárias, assessoria técnica para reformas

(2) A esse respeito, observe-se peculiaridades do Rio de Janeiro. Até a aprovaçāo do plano diretor, em 1992, o Legislativo abria māo do controle do uso e da ocupação do solo urbano em favor do Executivo, que fazia, por meio de decretos, uma forma bizarra de convívio da tecnocracia "independente" com interesse de grupos específicos. Mesmo hoje, quando o Executivo já recuperou a sua prerrogativa, essa situação histórica gerou uma legislação urbanística que é uma verdadeira colcha de retalho, certamente a mais intrincada do país. 
e intervençōes urbanas específicas, o Corredor Cultural atua por reciclagem de usos, da requalificação e da animação dos espaços públicos ${ }^{3}$ Consolidando-se nos anos 90 , o projeto foi plenamente incorporado ao processo de planejamento da cidade e logrou fomentar uma significativa revitalização econômica e cultural do centro.

\section{Uma Estratégia para a Recuperação do Rio de Janeiro}

Por isso, pode-se dizer que nos últimos anos, o Rio de Janeiro tem vivido uma verdadeira revolução urbanística, apoiada na instituição de um processo de planejamento estratégico, cujo plano foi elaborado de 1993 a 1995 (Prefeitura da Cidade, 1996 a \& b). Nas palavras do ex-prefeito Cesar Maia, "a cidade estava num processo de deterioração crescente, gerada pelo empobrecimento de sua população, pela ocupação desordenada dos espaços públicos $e$ privados, pela deterioração dos serviços públicos e pela fuga de capitais financeiros e humanos. Uma cidade sem vocações definidas, com uma identıdade distorcida, em processo crescente de desintegração... a reversão desse quadro exigia esforço maior do que seria capaz a ação individual do governo" (Prefeitura da Cidade, 1996b: 10) ${ }^{4}$

Com o apoio da Associação Comercial e da Federação das Indústrias, além da consultoria de uma equipe de Barcelona, o processo do plano estratégico baseia-se num comitê executivo, um conselho diretor e 31 grupos de trabalho com mais de 200 participantes entre técnicos, profissionais e representantes da sociedade, além da aprovação final pelo Conselho da Cidade. Fundamentando-se no reconhecimento das dificuldades e dos potenciais existentes no Rio, 0 plano também se respaldou em entrevistas com inúmeros membros representativos da sociedade e em sua aprovação final pelo Conselho da Cidade.

Apesar das críticas, particularmente, por conta de inspirar-se no modelo neoliberal e de sua relativa independência do Plano Diretor da Cidade, aprovado ainda no governo anterior (1992), o plano estratégico constitui importante esforço integrador e direcionador de programas e investimentos públicos e privados sobre a cidade, superando a visão estática e os programas ambiciosos que dominavam o planejamento centralizado. O plano estabeleceu sete estratégias, cada uma com os seus objetivos específicos, às quais estão apensos 159 projetos, dos quais $50 \%$ encontram-se em implantação, sendo que a prefeitura responde por $44 \%$ deles, o Estado por $24 \%$, o governo federal por $14 \%$ e a iniciativa privada por $17 \%$ (Prefeitura da Cidade, 1996b: 111 .

O Projeto Rio Cidade foi incluído na Estratégia 2: Rio Acolhedor, que visa a melhoria da relação entre o cidadão e o meio ambiente, a qualificação e fortalecimento da vida dos bairros e a melhoria dos espaços públicos. Já o Projeto Corredor Cultural foi incorporado à Estratégia 4:

(3) Vide RIOARTE/IPLANRIO (1985) e PINHEIRO (1986).

(4) Deve-se registrar que a experiência do planejamento estratégico em Barcelona, assim como as suas realizaçōes urbanísticas, têm servido de modelo para o Rio nas duas últimas gestōes, o que incluiu a précandidatura da cidade às Olimpíadas de 2004. 
Rio Integrado, que busca o desenvolvimento de novas centralidades e a revitalização do centro, a normalização urbanística e a mobilidade interna. Desta estratégia também participa o importante Projeto Favela Bairro, criado em 1994 e destinado a atender, em quatro anos, 90 comunidades faveladas com população estimada em 300.000 habitantes, com urbanização, implantação de infra-estrutura, eliminação de riscos ambientais, dotação de serviços e equipamentos, programas de geração de renda.

\section{As Bases do Projeto Rio Cidade}

Com o Projeto Rio Cidade, a prefeitura busca reforçar o caráter polinuclear do Rio de Janeiro e a especificidade da sua malha urbana de fundos de vales, privilegiando corredores viários comerciais, fortalecendo a identidade dos bairros e investindo na auto-estima das comunidades (Prefeitura da Cidade, 1997). De modo a instigar a discussão de novas idéias, a gerar soluções diferenciadas e a permitir o desenvolvimento simultâneo dos diversos projetos, a prefeitura inovou ao optar por contratar os projetos por meio de concursos públicos, promovidos pela Empresa Municipal de Informática e Planejamento (IPLANRIO) e o IAB-RJ ${ }^{5}$. Assim, o edital do primeiro concurso anunciava que o Rio Cidade iria "atuar sobre trechos estruturadores da imagem da cidade, revitalizando o conceito de rua e devolvendo-a aos cidadãos em condiçōes adequadas de uso, conforto e segurança".

Como concursos de metodologias para intervenção urbanística em corredores comerciais da cidade, as equipes concorrentes podiam utilizar ou não as áreas de projeto indicadas pela prefeitura para exemplificar as suas idéias, mas deveriam ser multidisciplinares, lideradas por arquitetos-urbanistas, com designer, paisagista e especialista em tráfego. No primeiro concurso, outubro de 1993, o júri selecionou 17 equipes, enquanto que no segundo, julho de 1997. foram 27; todas posteriormente contratadas e gerenciadas pela IPLANRIO, que se reservou o direito de decidir pelo valor dos contratos e em que área de intervenção alocar cada uma. Posteriormente ao primeiro concurso, duas novas áreas de intervenção foram incorporadas ao Rio Cidade, sendo um dos projetos desenvolvido pela própria IPLAN e outro contratado por concorrência pública.

As 46 áreas de intervençāo do Projeto Rio Cidade, em suas duas fases, distribuem-se por toda a cidade, do centro e bairros da zona sul aos subúrbios da zona norte e oeste ${ }^{6}$ Todas essas áreas sofriam de problemas tão comuns às metrópoles brasileiras, como passeios e mobiliário

(5) Para uma ampla cobertura do Rio Cidade e todos os projetos da primeira fase, veja-se Prefeitura da Cidade (1997).

(6) Áreas do Rio Cidade /: centro (av. Rio Brancol, zona sul (Botafogo, Catete, Copacabana, Ipanema, Laranjeiras e Leblon), zona norte (Bonsucesso, Ilha do Governador, Madureira, Méier, Pavuna, Penha, Tijuca, Vila Isabel e av. Suburbana) e zona oeste (Campo Grande e Taquara). Áreas do Rio Cidade /I: centro (av. Pres. Vargas e Santa Teresa), zona sul (Jardim Botânico), zona norte (Bangú, Benfica, Grajaú, rua Haddock Lobo, largo do Bicão, Irajá, Madureira, Mal. Hermes, Maracanã, av. Marques de Abrantes, Ramos, Realengo, Rocha Miranda e rua Uruguai) e zona oeste (Campo Grande, Freguesia, Pedra de Guaratiba, praça Seca e Santa Cruzl. 
urbano precários, desenho viário conflituoso, falta de arborização, invasōes de espaços públicos, abusos do comércio ambulante, poluição visual, conflitos na legislação urbanística etc. Tanto no Rio Cidade I quanto no II, os projetos respondem às temáticas do desenho urbano, paisagismo, mobiliário urbano, sinalização e comunicação visual, sendo que alguns propuseram, complementarmente, tombamentos, alterações na circulação viária e na regulamentação de uso e ocupação do solo; nessa fase, os levantamentos topográficos e projetos complementares ficaram sob a responsabilidade do IPLANRIO. No caso do Rio Cidade II, ainda em fase de desenvolvimento de projeto, as equipes assumiram a incumbência dos projetos complementares, além de terem de apresentar estudos de adaptação da legislação urbana aos impactos previstos pelas suas próprias propostas de intervenção.

Embora os projetos sejam tão variados quanto às equipes de trabalho e os bairros atingidos, pode-se dizer que, além das intervençōes assumidas pela própria prefeitura ladaptação da distribuição elétrica e eliminação da fiação aérea, repressão ao comércio ambulante e recuperação de redes de infra-estrutura) todos têm buscado: al melhorar as condições estéticas, de segurança e conforto, ampliando e requalificando os espaços peatonais, o mobiliário, a arborização e os sistemas de comunicação; bl melhorar as condições de trânsito, de estacionamento, carga e descarga e paradas de ônibus; c) integrar as soluções projetuais. Em 1996, 15 projetos do Rio Cidade I já haviam sido implantados, totalizando investimento superior a $R \$ 200$ milhões, dos quais aproximadamente $60 \%$ destinaram-se a obras de infra-estrutura.

\section{- Projeto Rio Cidade Méier: funcionalidade e Propriedade das Soluçóes}

Típico bairro de subúrbio carioca, a menos de 10 km do centro, a urbanização do Méier consolidouse com a expansão urbana ao longo da ferrovia e das estradas marginais, a construção da estação e as novas linhas de bonde, que fizeram dele uma importante opção residencial para a classe média e um dos mais importantes bairros da zona norte carioca. Graças à situação de "passagem" entre o centro e bairros mais ao norte, o "subcentro funcional" do Méier atrai muitos milhares de compradores e passageiros - trens, ônibus e carros - em sua jornada para o trabalho, sendo uma das áreas comerciais da cidade.

No Projeto Rio Cidade Méier, a prefeitura destacou o escritório Mayerhofer \& Toledo para intervir em uma área de pouco mais de 5 hectares do subcentro funcional, em ambos os lados da via férrea ${ }^{7}$ Tendo perdido a sua identidade e encontrando-se muito deteriorada, fisica e funcionalmente, a área sofria, ainda, sérios problemas causados pela ocupação urbana desordenada, pelo trânsito caótico e pelo descaso histórico das autoridades em relação à

(7) Equipe principal na Mayerhofer \& Toledo: Luiz Carlos Toledo, responsável; Vicente del Rio, coordenaçāo e desenho urbano; Vera Tângari, paisagismo; Mario Ferrer, Lilian Nóbrega e Luiz Claudio Franco, arquitetura e design. 
apropriação, uso e manutenção dos espaços públicos (Foto 1). Por outro lado, as condições topográficas e o processo de parcelamento haviam gerado um tecido urbano de baixa continuidade, situação agravada pela barreira representada pela via férrea.

Além dos temas tradicionais constantes em diagnósticos, a metodologia adotada no projeto para o Méier considerou a evolução morfológica, as expectativas e imagens ambientais, a paisagem e a configuração espacial, o comportamento dos transeuntes e a apropriação dos espaços públicos. Daí, foram concluídas cinco metas conceituais para as soluções de projeto: imagem/ identidade, continuidade funcional e físico-espacial, visualidade/legibilidade, conforto/segurança e variedade. Além disto, a equipe decidiu que todas as soluções deveriam ser simples, baratas e de fácil execução, particularmente no tocante ao mobiliário urbano, uma vez que, no caso do Méier, interessava mais a funcionalidade, a segurança no uso e o acesso ao equipamento do que um design exclusivo, caro e de difícil reposição; optou-se, sempre que possível, pela reutilização de mobiliário já adotado pelas concessionárias, com as modificações necessárias.

Motivo de maior atenção no projeto, era sintomática a situação da rua Dias da Cruz, principal acesso ao Méier desde a estação e importante via de penetração para outros bairros. Nos anos 50 ,

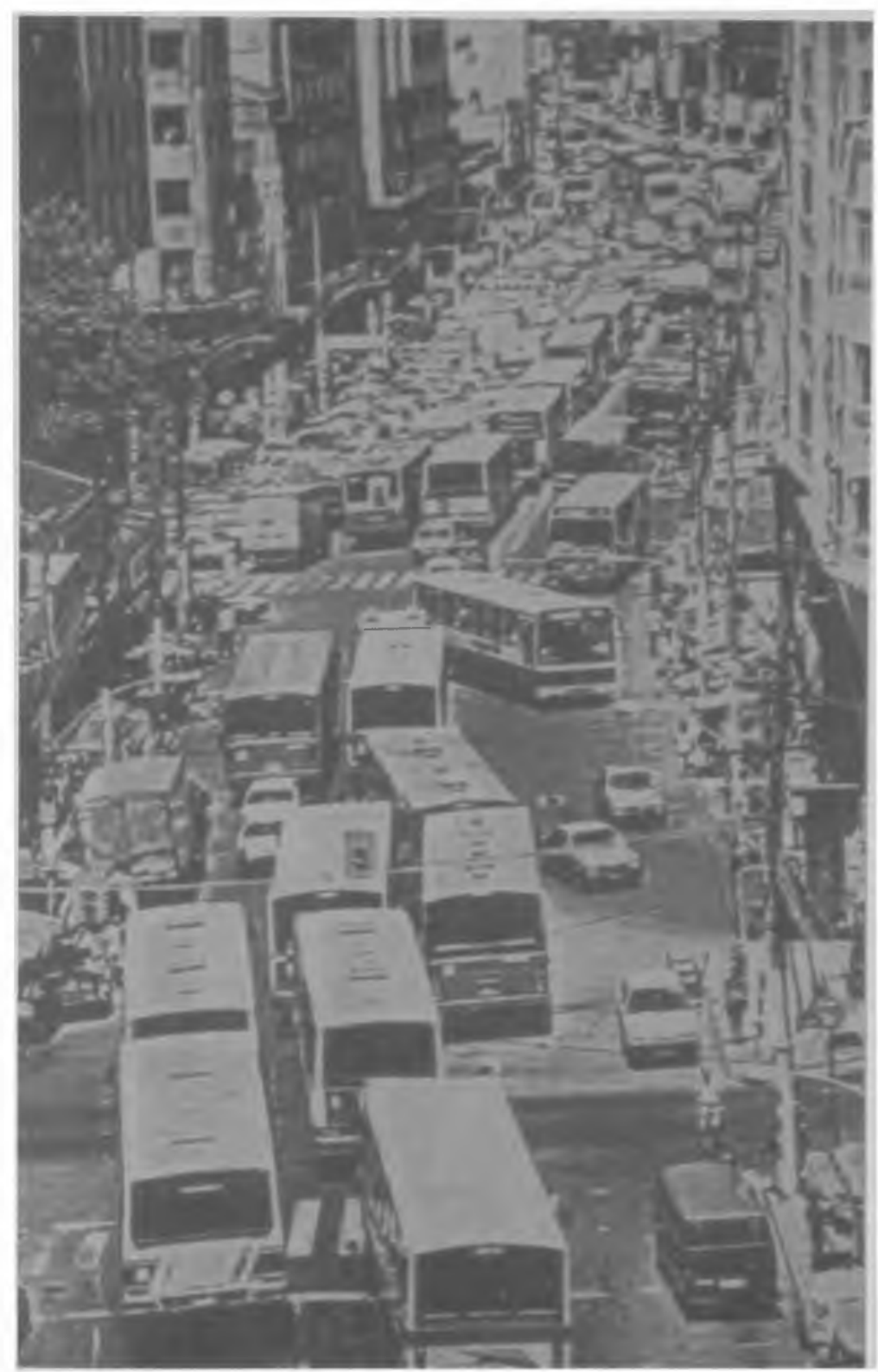

Foto I: Trânsito caótico, ocupação desordenada e descaso com o espaço público; a rua Dias da Cruz, principal corredor funcional do centro do Méier em 1993, antes do Projeto Rio Cidade

Fonte: divulgação, IPLAN-Rio

quando o bairro era a "capital dos subúrbios", nessa rua foi inaugurado o Imperator, então o maior cinema da América Latina, com 2.000 lugares e hoje transformado em famosa casa de espetáculos. Foi lá também que, em 1965, confirmando a sua vocação comercial, foi inaugurado "o primeiro shopping center do Brasil" ${ }^{8}$ Atualmente, a rua Dias da Cruz possui grande concentração comercial ao longo de seus três primeiros quarteirões, desde a estação de trens e na direção do Shopping do Méier, onde, em prédios com altura média de oito pavimentos, há várias galerias comerciais, duas lojas de departamentos, grandes lojas de eletrodomésticos e de fast-food.

Paisagem
Amblente
Ensaios
13

São Paulo n. 13 p. 0928 dez. 2000 
Com trânsito nos dois sentidos em quase toda a sua extensão, as quatro faixas de rolamento da rua Dias da Cruz não davam conta do volume de trânsito devido à sua geometria irregular, ao estacionamento caótico e à falta de baias para ônibus, aos giros à esquerda e retornos proibidos, a dois cruzamentos bastante complicados e as quase 50 linhas de ônibus que por lá passavam (vide foto 1). Os pedestres disputavam com os carros e os mais de 200 camelôs, as estreitas e malconservadas calçadas, desprovidas de qualquer arborização, mobiliário ou sistema de sinalização.

Assim, sua importância e pela situação em que se encontrava, pode-se dizer que a reestruturação da rua Dias da Cruz foi o que mais se destacou no Rio Cidade Méier, pois resultou numa significativa melhora dos fluxos veiculares e no aumento do conforto dos pedestres. A melhoria na circulação de veículos foi garantida por uma nova geometria viária com caixas de rolamento constantes da construção de um canteiro central (com fileira de palmeiras e postes de iluminação com chicote duplo) e de baias laterais (para ônibus, táxi e carga/descarga), da eliminação de uma "ilha" de trânsito em importante cruzamento com a principal artéria de volta ao centro, além da proibição de estacionamento em sua extensão e modificação de linhas de ônibus. A decisão da administração regional de fechar a rua Dias da Cruz ao trânsito nos domingos, transformando-a em "rua de lazer", também tem contribuído positivamente para o resgate da qualidade do bairro.

Em toda a área de intervenção, os passeios foram substancialmente alargados e receberam farta arborização, equipamentos e mobiliário de apoio prevendo-se, também, um sistema de pocket plazas, nos quais os maiores espaços livres receberam tratamento paisagístico diferenciado. Todo o desenho de piso explorou padrões geométricos em placas de concreto pigmentado, de modo a marcar a identidade da área, lembrar a cultura colorida de subúrbio carioca e reforçar a continuidade entre os dois lados da via férrea. Em todos os passeios garantiu-se largura mínima livre de quaisquer barreiras, faixa esta demarcada por fiadas de pedras tipo "miracema" e pisos de alerta para deficientes visuais. Entre essa faixa e o meio-fio foram locados todos os elementos de mobiliário e paisagismo sendo que, originalmente, o seu desenho de piso previa a locação organizada dos camelôs, cada um com o seu número de inscrição oficial na prefeitura, estampado no piso do seu "espaço" ${ }^{9}$ Todos os desníveis foram rampeados, em todas as travessias o canteiro central da rua Dias da Cruz foi interrompido e os meio-fios rebaixados (com o nome da rua estampado no topo das rampas), foram instalados postes de luz para pedestres, totens de orientação nas esquinas e semáforos, além de, em diversos locais, mapas indicativos com pontos e lojas de interesse.

(8) Esse foi, realmente, o primeiro shopping center construído no Brasil, embora nāo seja reconhecido como tal porque alguns aspectos do empreendimento o desclassificam perante Associação Brasileira de Shopping Centers - ABRASCE. Vide Del Rio, V. et al, 1987.

(9) Alterado no projeto final porque a prefeitura decidiu-se por um decreto proibindo que camelôs permanecessem nas áreas do Rio Cidade. 
No início da rua Dias da Cruz, marcando a principal entrada do bairro desde o centro da cidade, o pequeno Largo do Méier foi totalmente redesenhado. Ali, um grupo escultórico de chapas verticais em fibra de vidro, nas cores azul e verde, "mordidas" com a palavra Méier e assentadas sobre a grelha metálica que protege chafarizes e holofotes geram um efeito colorido todo especial e atraem a atenção dos transeuntes (Foto 2 ) $^{10}$

Logo acima, ainda na rua Dias da Cruz, a praça Agripino Grieco, de pequeno porte, era desprovida de equipamentos, sofria com o descaso e seus canteiros eram pisoteados pelos usuários de dois pontos finais de ônibus. O novo desenho, centralizado em pedestal com o busto do poeta, incluiu anfiteatro, pequena área de playground, bancos e mesinhas para jogos, quiosques de

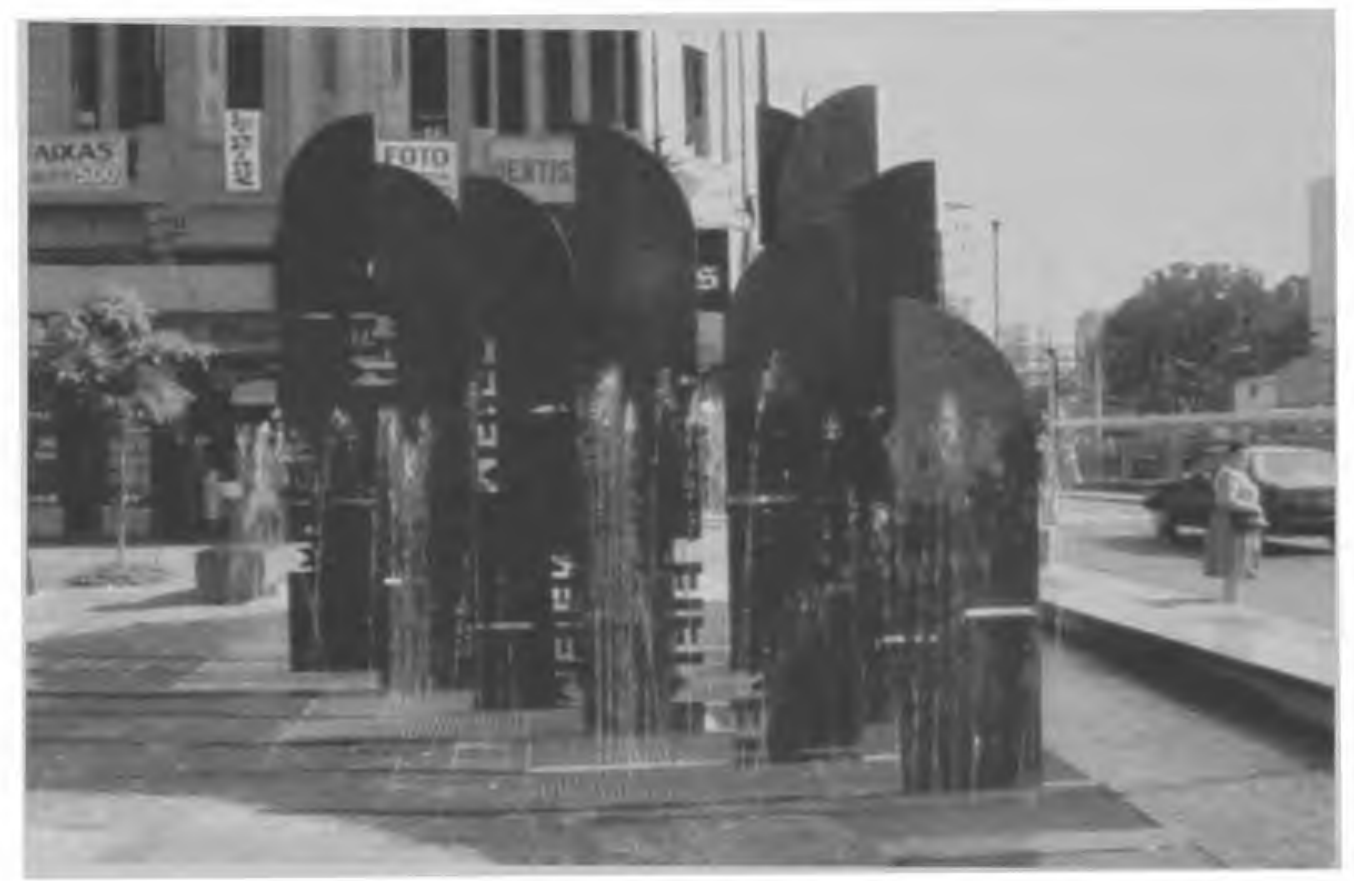

Foto 2: Uma nova pracinha com grupo escultórico e chafarizes como marco de entrada ao centro do Méier Fonte: Celso Brando

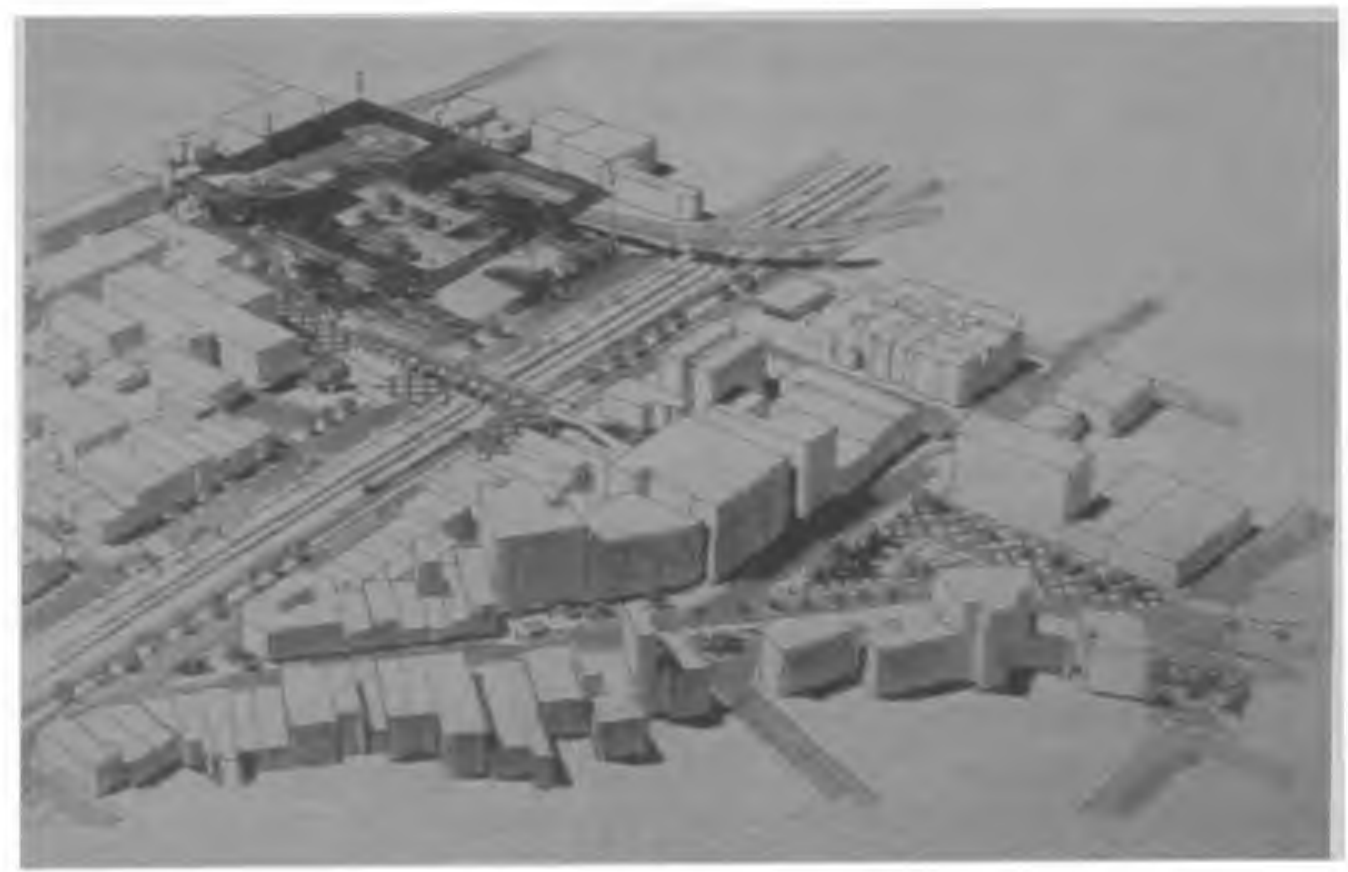

Foto 3: A perspectiva do estudo preliminar (1994) mostra a nova praça Agripino Grieco, o marcante desenho de piso, a implantação de áreas de pedestres e a nova passarela estendida desde o Jardim do Méier, pela galeria comercial existente

Fonte: perspectiva, de Eduardo Rocha

(10) Originalmente idealizadas em aço, com a ferrugem superficial do tempo, essas chapas lembrariam da ligação do bairrro com a ferrovia, o que foi, infelizmente, inviabilizado pelos custos projetados. 
flores e de alimentação, além de reforçar a arborização existente (Fotos 3 e 4). Os pontos finais de ônibus foram deslocados para um novo terminal e no seu entorno novas ruas de serviço e passeios alargados reforçaram a concentração de usuários no happy hour (Foto 5). Perto daí, numa pequena área abandonada junto à alça do viaduto foi construída uma pracinha com brinquedos para crianças e pista de skate, única da regiāo e que hoje atrai dezenas de jovens.

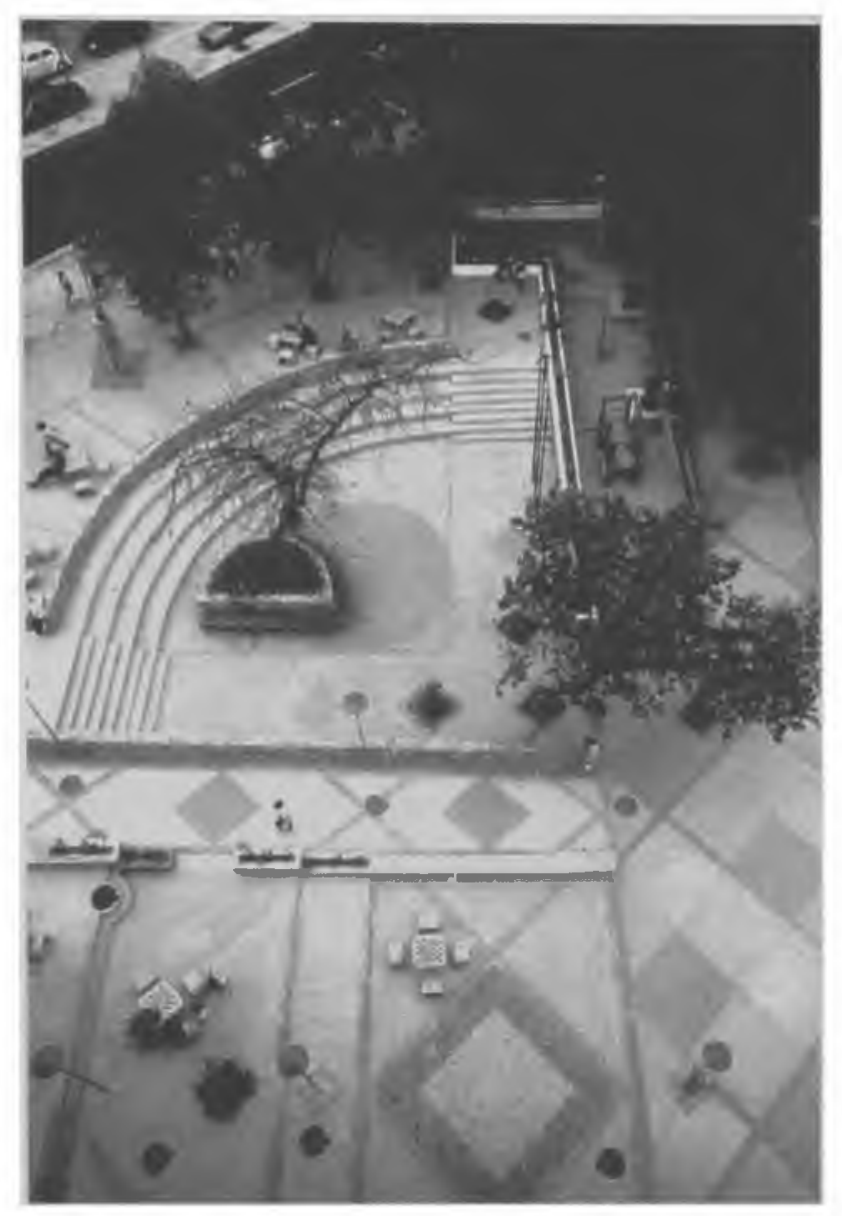

Foto 4: Detalhe da mesma praça já reformada, mostrando o anfiteatro, rampas, jardineiras e 0 desenho de piso realçando o desenho do conjunto Fonte: Divulgação (IPLAN-Rio)

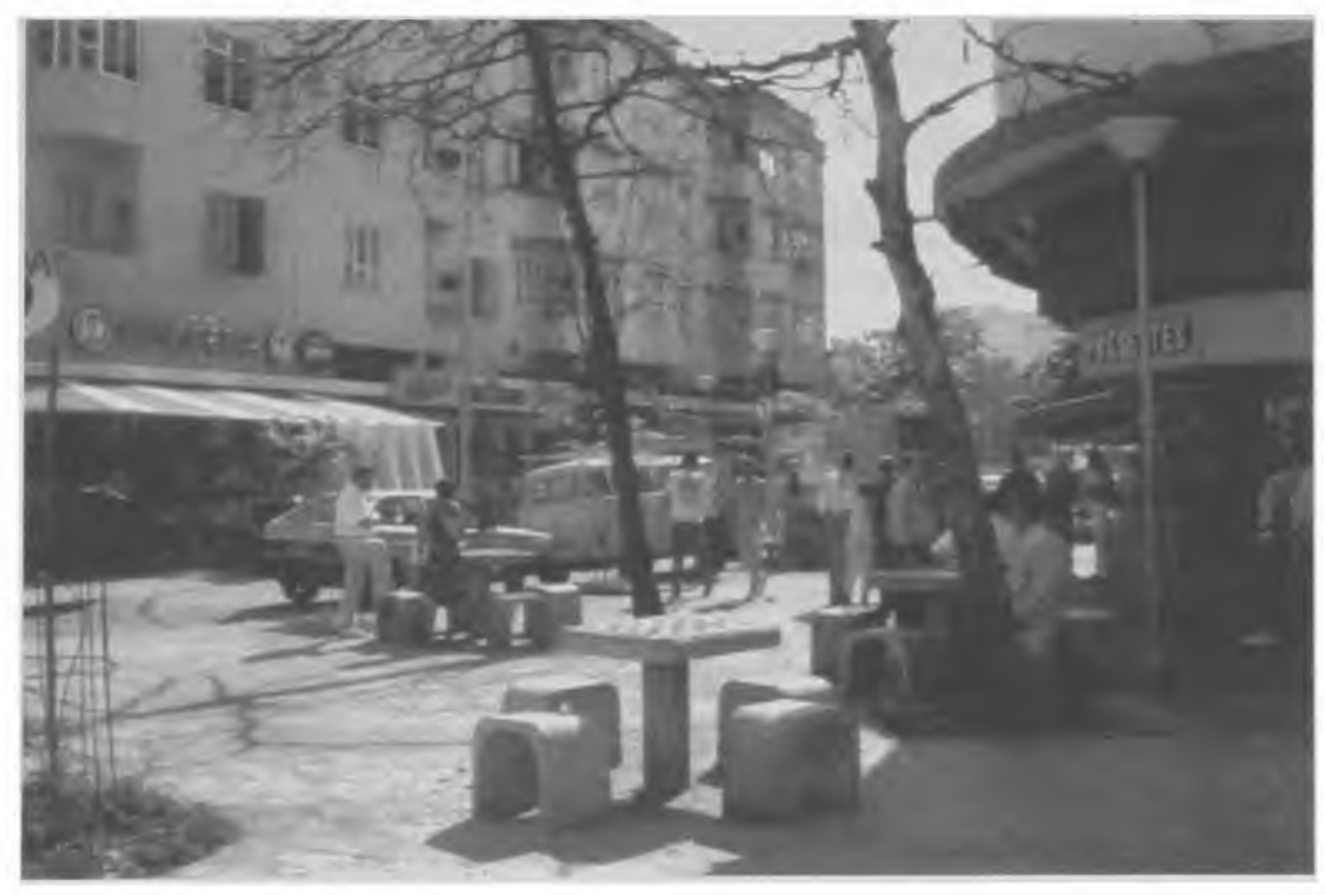

Foto 5: No entorno da praça Agripino Grieco, esta pocket plaza com suas mesas e cadeiras ajudou a implantar o que é hoje um animado happy hour na área Fonte: V. del Rio 
A passarela sobre a linha férrea foi reformada com a instalação de novas rampas e de cobertura em fibra colorida e iluminada, marcando a passagem pelo bairro (Foto 6). A desapropriação de dois imóveis possibilitou que ela fosse estendida sobre a avenida e conectada a uma galeria comercial, permitindo ao pedestre chegar diretamente na praça Agripino Grieco, na rua Dias da Cruz e em um novo miniterminal de ônibus desde a plataforma da estação ou o outro lado do Méier, onde estão o Jardim do Méier, um hospital municipal e outros importantes serviços públicos. Essa nova articulação, além de aumentar a continuidade entre os dois lados seccionados do bairro, melhorou significativamente a sua capacidade como função intermodal.

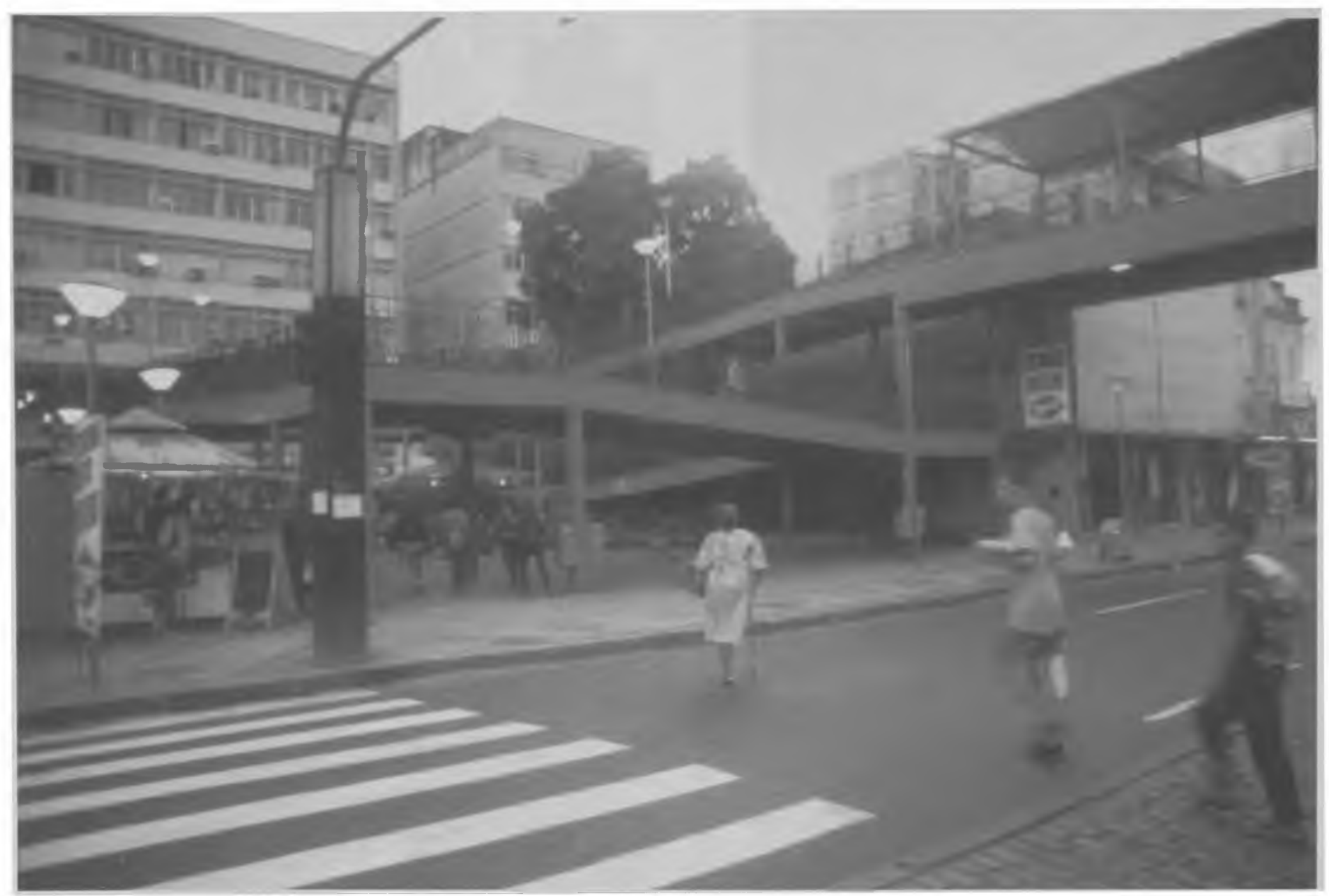

Foto 6: A passarela foi reformada, estendida e dotada de novas rampas e cobertura, conectando os dois lados da via férrea e as duas únicas praças de porte do Méier

Fonte: Vicente del Rio

Outro conceito importante do projeto foi o de "ilha de serviços" um abrigo que reúne, sob cobertura simples em chapa de aço com iluminação indireta, equipamentos de apoio: telefones públicos, mapa da área, cesto de lixo, banco e, originalmente, caixas de correio (não adotado por negativa da EBCT). Distribuídas por toda a área de projeto, a "ilha de serviços" permite fácil identificação, uso confortável e seguro. Variaçōes foram adotadas como abrigos para pontos de ônibus e táxi (Foto 7).

20 \begin{tabular}{|l|}
$\begin{array}{l}\text { Paisagem } \\
\text { Ambiente } \\
\text { Ensaios } \\
13\end{array}$ \\
\cline { 2 - 2 }
\end{tabular}

São Paulo n. 13 p. 0928 dez. 2000 


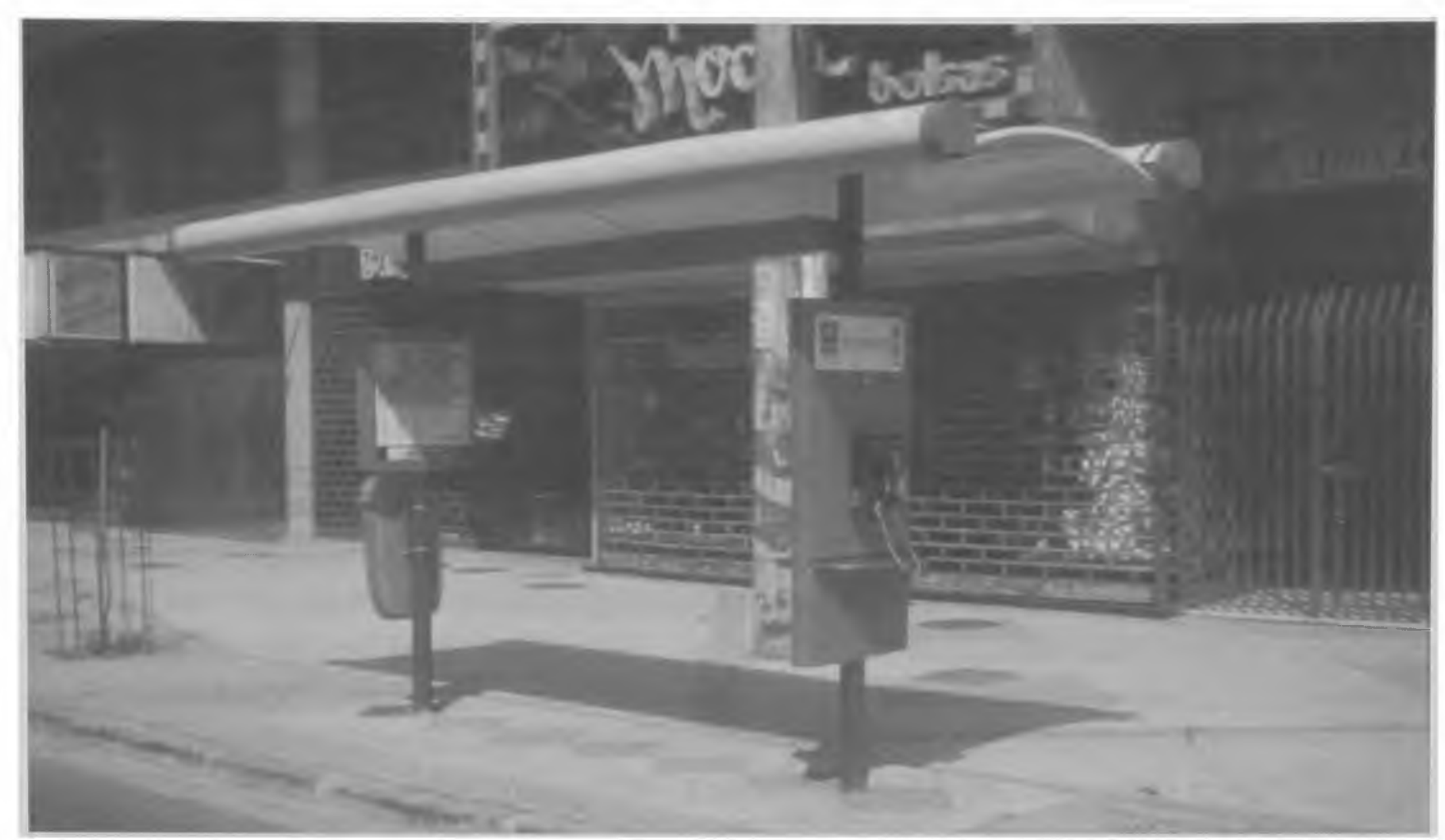

Foto 7: O novo abrigo de ônibus, uma variaçăo da "ilha de serviços", no Méier Fonte: Vicente del Rio

Finalmente, o sistema de comunicação visual para a área incluiu a adoção das cores laranja e verde em todos os elementos de mobiliário, e o uso de logotipo próprio, inspirado no canteiro central com palmeiras, de modo a implantar uma "marca" distinta para o Méier.

A obra foi iniciada em dezembro de 1995 e inaugurada em setembro do ano seguinte, sendo que a parte do projeto relativa ao lado norte da linha férrea, oposto à área fortemente comercial, ainda não foi implantada. O custo total da obra executada foi de aproximadamente R\$ 15 milhões, incluindo a infra-estrutura e, por exemplo: $26 \mathrm{~km}^{2}$ de ruas pavimentadas e $25 \mathrm{~km}^{2}$ de passeios, 1,4 km de galerias pluviais, 206 coletores de lixo, 19 abrigos de ônibus, 359 postes de iluminação e 460 árvores. Assim como em todas as áreas do Rio Cidade l, todas as redes aéreas foram embutidas, garantindo uma verdadeira "limpeza" visual, resultado muito bem visto pela própria população.

Com a implantação do projeto verificou-se melhoras significativas no fluxo viário, as calçadas são utilizadas mais facilmente, foram minimizados conflitos entre veículos e pedestres, as áreas públicas passaram a ser utilizadas intensamente, inclusive por crianças, e houve clara valorização dos pontos comerciais o que, por sua vez, irá suscitar novos investimentos. Isto se verifica especialmente ao longo da Dias da Cruz e no entorno da praça Agripino Grieco, com a consolidação do "Baixo Méier" (apelido inspirado nas tradicionais áreas de boemia do Leblon e da Gávea, bairros da zona sul cariocal e a reforma de bares e restaurantes, abertura de novos pontos comerciais, como duas conhecidas cadeias de fast-food, além da reforma do velho Cine Art Méier para exibir filmes do circuito comercial. 


\section{- Projeto Rio Cidade leblon: elegáncia do Design e do Paisagismo}

No fim da República Velha, a ocupação do Leblon ainda se iniciava, principalmente por moradias dos grupos de renda mais elevada (Abreu, 1986). Foi apenas após o ápice de Copacabana e da capitalização do status de morar junto ao mar, nos anos 50, que o bairro passou a viver o seu boomimobiliário. Hoje, ele é um dos bairros de maior poder aquisitivo do Rio de Janeiro, com elevado índice de áreas verdes, praças e ruas relativamente bem cuidadas e arborizadas, e o comércio mais intenso, bastante seletivo, concentrando-se ao longo da avenida Ataúlfo de Paiva, principal artéria que atravessa todo o bairro paralelamente e a duas quadras da praia.

Concentrando o Projeto Rio Cidade do Leblon nesta avenida - assim como em Ipanema e Copacabana ao longo das avenidas Visconde de Pirajá e N. Sa. Copacabana - a prefeitura dispôs-se a remodelar um dos mais importantes eixos que ligam a zona sul ao centro, promovendo o seu tratamento urbanístico diferenciado por bairro, numa decisão, aliás, que suscitou algum questionamento. Por concentrar grande parte do fluxo viário e todas as linhas de ônibus para Ipanema, Copacabana e centro, assim como pelo uso misto (residencial, comércio e serviços) em prédios de, em média, dez pavimentos, a avenida Ataulfo de Paiva sofria os problemas e conflitos típicos. Além disto, em uma de suas extremidades, consolidouse o "Baixo Leblon", área com grande número de bares e restaurantes, alguns abertos 24 horas, que se tornou referência noturna na cidade. Ainda ao longo da avenida: galerias comerciais e inúmeras agências bancárias, duas filiais do MacDonald's, o tradicional cinema Leblon (duas salas), uma igreja católica e um shopping de design, além da importante praça Antero de Quental.

O Projeto Rio Cidade Leblon, abarcando uma área de 6,4 hectares e todos os 1,5 km de extensão da avenida, foi de responsabilidade de Índio da Costa Arquitetura " Diferentemente do caso do Méier, em que os arquitetos concentraram-se na funcionalidade e na propriedade das soluções em área de subúrbio muito problemática, no Leblon, bairro de alta qualidade ambiental, a equipe optou pela requalificação, principalmente, do esmêro nas soluções de paisagismo e de design. Aqui, os objetivos gerais do projeto foram: enfatizar a tendência para as atividades de lazer, reordenar o trânsito e ampliar as áreas dos pedestres (Prefeitura da Cidade, 1997).

Como não poderia deixar de ser, e a exemplo de quase todos os Rio Cidade, a avenida Ataulfo de Paiva concentrou a atenção do projeto. A via foi redesenhada em toda a sua extensão, disciplinando-se os estacionamentos, as paradas de ônibus e a carga/descarga, sempre por meio de bainhas, suavizando-se a curvatura das esquinas e rampeando-se todos os locais de

(11) Equipe principal: Luiz Eduardo Índio da Costa, responsável; Fernando Chacel, paisagismo; Luiz Augusto índio da Costa, design.

\begin{tabular}{|l|l|l|l|}
\hline 22 & $\begin{array}{l}\text { Paisagem } \\
\text { Ambiente } \\
\text { Ensaios } \\
13\end{array}$ & São Paulo n. 13 p. $09 \quad 28$ dez. 2000 \\
\cline { 2 - 4 } & & & \\
\hline
\end{tabular}


travessias sendo que, onde há grande movimento de pedestres, toda a extensão da esquina foi rampeada. Todos os passeios foram alargados, dotados de bancos e amplas jardineiras, e a sua pavimentação recebeu esmerado e elegante mosaico de padrões curvilíneos em pedras portuguesas brancas, pretas e vermelhas, bem ao estilo carioca.

O projeto propôs uma extensão mais significativa da área destinada ao uso dos pedestres em dois locais principais da avenida Ataulfo de Paiva. Ao longo de dois quarteirōes de uma das avenidas que nela desemboca, junto à pequenina praça Cazuza na área do "Baixo Leblon" previa-se a pedestrianização, de modo a incentivar as extensões dos bares e restaurantes e a reforçar o caráter boêmio do lugar; esta solução não foi implantada por resistência da população receosa das transformações e do fechamento ao trânsito. Em outro local, importante cruzamento com uma via de mão dupla, a geometria original das esquinas e seus prédios, em $45^{\circ}$ ao estilo "barcelona", foi alterada para o tradicional ângulo reto, gerando pocket parks com jardineiras, arborização, bancos e quiosques de flores e revistas.

A praça Antero de Quental, ocupando todo um quarteirão, sempre foi importante área de lazer do bairro, bem equipada, arborizada e muito freqüentada durante todo o dia. O projeto soube maximizar esse potencial, mantendo e setorizando os seus usos pela reorganização física e paisagística (Foto 8). Todo o piso da praça foi elevado em um degrau em relação ao meio-fio original para maior proteção dos usuários, os idosos ganharam mesas e bancos à sombra, as crianças um novo playground rebaixado e protegido por elegantes jardineiras em pedra e os usuários em geral vários bancos e iluminação apropriada de baixa altura. Junto à avenida Ataulfo de Paiva, um grande pergolado na cor vermelha e parcialmente protegido com chapas de policarbonato serve como popular quiosque para venda de plantas. Outros pergolados foram distribuídos no perímetro junto ao passeio e ajudam na definição paisagística do novo desenho da praça.

No Projeto Rio Cidade Leblon, um dos maiores destaques é, sem dúvida, o design elegante e funcional de todo o seu mobiliário urbano. O novo poste permite a iluminação diferenciada para a caixa da rua e as calçadas, agora bem iluminada por luminária com placa difusora da luz indireta de um holofote. Nas esquinas, quatro

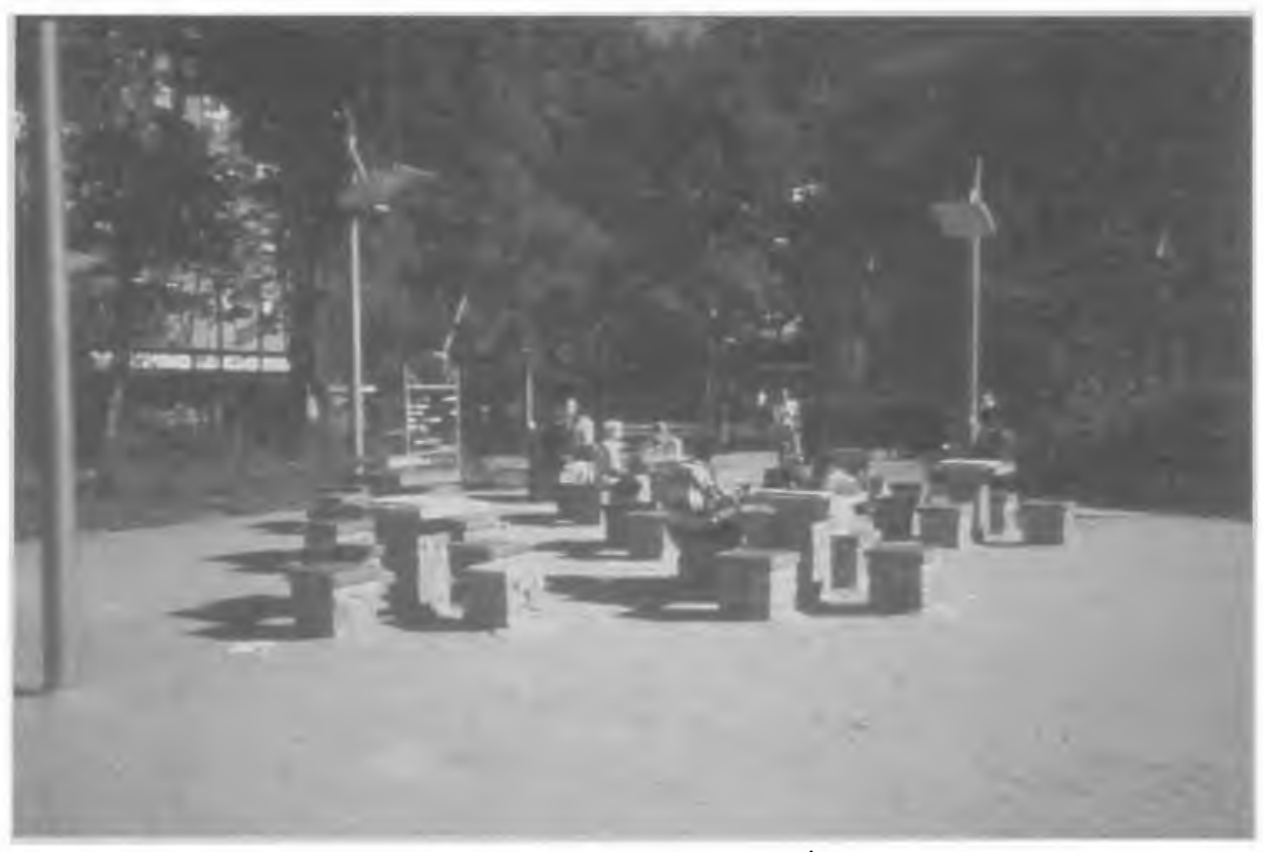

Foto 8: O Projeto Rio Cidade Leblon reformou a já concorrida praça Antero de Ouental, elevando-a a outro patamar de qualidade, com novos desenho e elementos, tais como iluminação, mobiliário, jardineiras e canteiros, além de uma setorização melhor definida

Fonte: Vicente del Rio 
destes postes incorporam a sinalização vertical e semafórica, garantem forte iluminação e destacam o seu papel no tecido urbano, aumentando a segurança de pedestres e motoristas (Figura 9). Acoplado aos postes e com forma arredondada, o design dos novos orelhōes tira proveito da transparência dos materiais para maior segurança do usuário (Foto 10). A solução para o abrigo nas paradas de ônibus se sobressai por sua leve estrutura metálica de apoio único, onde se fixam quatro assentos e uma luminária acima do plano da cobertura, em chapa de aço perfurada e policarbonato translúcido (Foto 11 ).

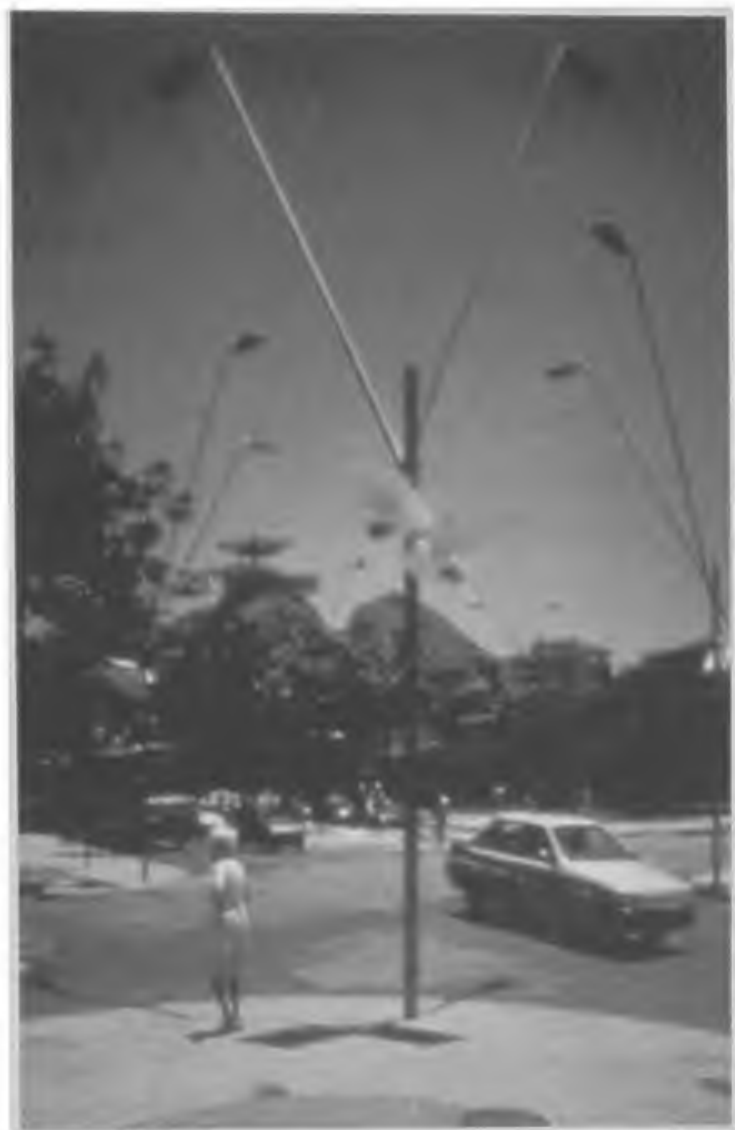

Foto 9: O novo poste de design elegante, integrando sinalização, iluminação veicular e de pedestres, numa esquina do Leblon Fonte: Vicente del Rio

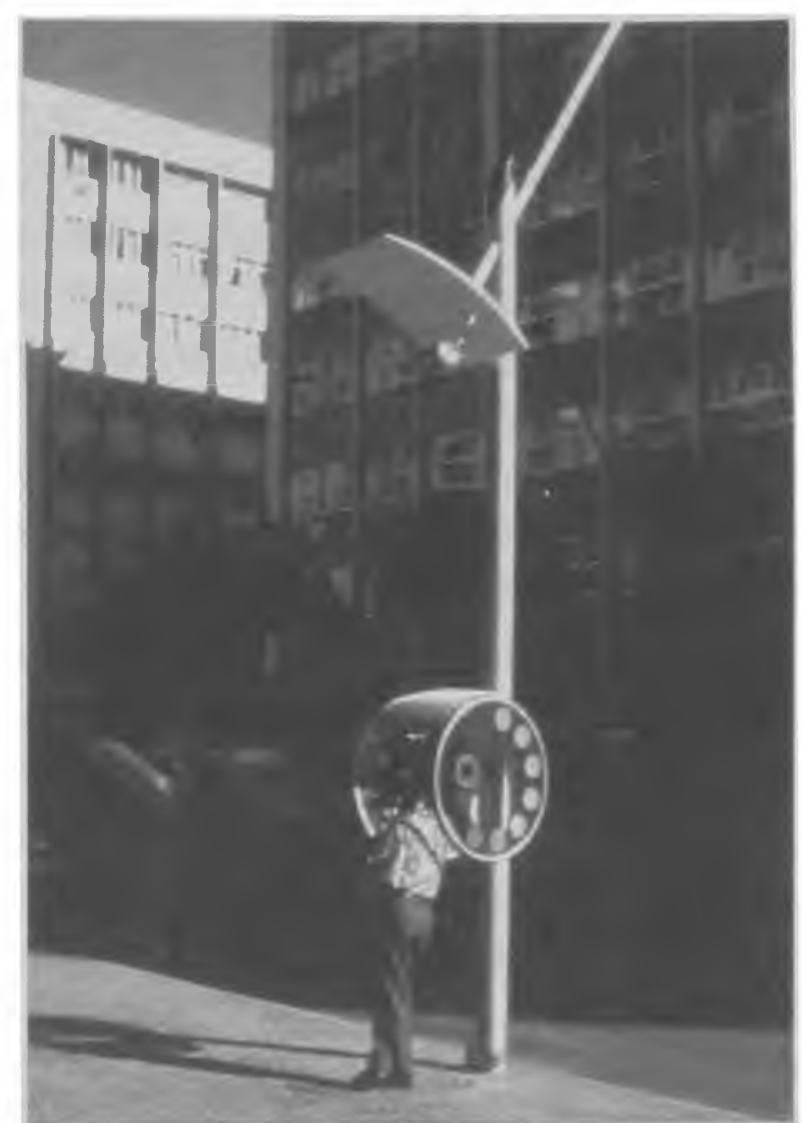

Foto 10: O poste com ilu-minação de pedestres recebe o novo orelhão de material transparente Fonte: Vicente del Rio

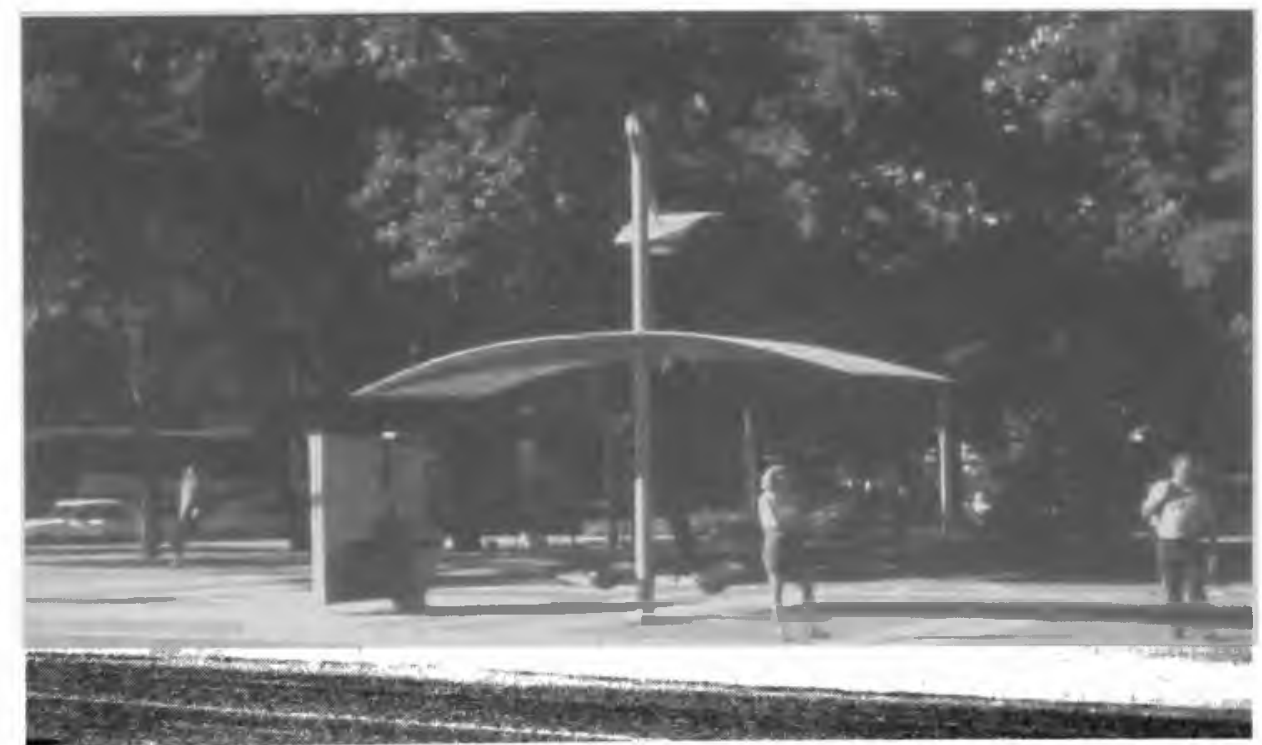

Foto 11: No Rio Cidade Leblon, o abrigo das paradas de ônibus - um dos elementos do mobiliário de maior destaque por sua arrojada solução e transparência - com bancos de fibra e espaço publicitário

Fonte: Vicente del Rio 
Outro ponto alto do projeto foi o capricho do detalhamento arquitetônico em geral, com soluções inovadoras, tais como o uso de granito branco: em rampas e na beira dos passeios ele foi utilizado em placas e, nos meios-fios, os seus blocos foram aparelhados com quinas vivas. O piso de todos os passeios foram dotados de faixas e soluções de alerta para cegos, marcando as travessias e a localização dos orelhões.

No Rio Cidade do Leblon, as obras foram iniciadas em fevereiro e inauguradas em dezembro de 1996, sendo o custo total aproximado de R\$ 15 milhões. O projeto incluiu $25 \mathrm{~km}^{2}$ de ruas pavimentadas e $27 \mathrm{~km}$ de passeios, $0,7 \mathrm{~km}$ de galerias pluviais, 467 postes de iluminação, 561 novas árvores, 8 abrigos de ônibus e 121 coletores de lixo. O resultado foi extremamente positivo, pois o projeto soube requalificar um bairro que já era privilegiado dentro do contexto carioca, por soluções muito especiais de design e paisagismo. Os passeios, alargados e bem arborizados, com bonitos mosaicos de piso e jardineiras, alegram a vida do bairro e potencializam o uso noturno dos bares e restaurantes.

\section{Uma Avaliação Preliminar do Projeto Rio Cidade}

Certamente, o Projeto Rio Cidade deverá suscitar muita pesquisa, estudos de desempenho e avaliações de resultados, e cabe-nos aqui ensaiar uma breve avaliação preliminar deste projeto totalmente inovador no contexto brasileiro e, até mesmo, no internacional, que se mostrou um verdadeiro "laboratório urbanístico" Tomando-se por base os dois casos aqui discutidos, mas com uma visão mais ampla de todo o processo, cabem algumas questões técnicas.

Em nível conceitual, questionou-se muito a propriedade de projetos de desenho urbano pontuais em áreas às vezes não-prioritárias e a que muitos chamaram de simples "maquiagem" antes mesmo da existência de maiores definições estruturais e territoriais, se visto sob um prisma mais tradicional do planejamento urbano. Esta questão pode ser respondida, primeiramente, em função do tempo que se levaria para elaborar planos tradicionais, identificar áreas prioritárias nos bairros e decidir por uma priorização criteriosa. Além disto, no caso do Rio Cidade I, embora a maioria dos projetos não tenha induzido grandes alterações estruturais (poucos propuseram alterações significativas na circulação viária, como foi feito no Méier, por exemplol todos geraram importantes melhorias funcionais e nas redes de infra-estrutura. Mas talvez acima de tudo, em face da deterioração urbanística e imagética da grande maioria das áreas e do Rio de Janeiro como um todo urgiam ações rápidas e localizadas, que pudessem atrair a atenção para as melhorias na cidade e gerar efeitos multiplicadores de curto prazo.

Já no aspecto gerencial, alguns conflitos identificados ao longo do desenvolvimento do projeto mostram-se de difícil, mas não impossível superação. Não diferentemente da maioria das cidades brasileiras, a máquina de gestão urbana, os órgãos competentes e seus técnicos acostumaram-se a práticas diferentes, metodológica, processual e temporalmente. No Rio Cidade I, muitos deles não possuíam critérios ou normas técnicas claras para orientar ou avaliar os projetos, outros se mostravam herméticos às inovações, enquanto tendiam a defender os seus "feudos" Essa situação era sintomática nas questões relativas à circulação e ao transporte 
público, pois os técnicos responsáveis por diferentes áreas da cidade, muitas vezes sem embasamento, faziam exigências até mesmo antagônicas das equipes de projeto, isto sem contar com as suas mudanças de opinião ao longo do tempo. Já no Rio Cidade II, a prefeitura e suas concessionárias prepararam-se para enfrentar esses problemas com a definição de diretrizes gerais e normatizações claras, previamente distribuídas às equipes contratatas para desenvolver os projetos de cada área.

O Rio Cidade tem sido útil para que o executivo municipal reaprenda a trabalhar, uma vez que a tradição da obra pública integrada havia há muito sido perdida. Demonstra-se a possibilidade da gestão urbanística por meio de ações setoriais integradas, o município atuando como coordenador. Neste sentido, destaca-se também a experiência que o poder público vem ganhando no gerenciamento concomitante de diversas equipes, projetos e obras. A este movimento positivo, o poder público começa também a aprender a responder com clareza na definição de diretrizes gerais, mas assumindo, ao mesmo tempo, uma maior abertura para aceitar soluções diferenciadas, maior flexibilidade e agilidade na avaliação e nas respostas.

Uma questão gerencial que precisaria ser reavaliada, pois perpassa todas as outras e é definidora do próprio teor dos projetos, é que a prefeitura não providenciou nenhuma previsão de investimentos em que as equipes pudessem basear o seu trabalho. Se, por um lado, esta liberdade tende a possibilitar soluções mais criativas, como argumenta a prefeitura, pelo outro lado, deixa as equipes duvidosas sobre os seus próprios limites projetuais, onera as obras e a manutenção das áreas.

Aliás, além do baixo nível da execução das obras da maioria das áreas - que se supõe causado pela pressa do calendário eleitoral - o maior problema que aflige o Rio Cidade é a sua conservação e a manutenção dos equipamentos e mobiliários diferenciados. Se, por um lado, a idiossincrasia das soluções levaram a maior individualização das áreas de projeto no contexto da cidade, pelo outro lado a não-padronização dos elementos e revestimentos onera o poder público, arrisca que sejam substituídos por outros totalmente diferentes e, nos casos relativos à comunicação visual, pode chegar a confundir os usuários. Resta resolver, ainda, outras questōes: a indisciplina dos motoristas que, quando não reprimidos, continuam a estacionar fora das bainhas de estacionamento e utilizam-se dos meios-fios rebaixados para estacionar nas calçadas, principalmente à noite; o vandalismo particularmente intenso em alguns bairros da zona norte; a conservação das inúmeras novas jardineiras; a limpeza geral das áreas.

Na questão de projeto, algumas metodológicas. A primeira diz respeito à relativa inexperiência tanto dos escritórios quanto da prefeitura em projetos desse tipo, assim como ao exíguo tempo exigido para o desenvolvimento do projeto, particularmente nas etapas de diagnóstico e estudo preliminar, relegados a três meses no total. Isto acabou por gerar algumas soluções impróprias de projeto, seja conceitualmente, por incompreensão dos fenômenos urbanos, das especificidades do contexto ou de aspectos psicossociais dos usuários, seja por falta de maior detalhamento. 
Mas é justo observar que durante o desenvolvimento dos projetos e das obras, apesar da urgência de todo o processo, a população sempre pôde expressar-se por meio das associações representativas e em reuniões de divulgação promovidas pela prefeitura, suscitando em alguns casos, mudanças significativas, como relatamos no caso do Leblon. Superado o ineditismo do Rio Cidade I, a segunda e atual fase tem possibilitado processos bem mais participativos entre as equipes de projeto, a prefeitura e a população, incluindo-se, por exemplo, reuniōes noturnas periódicas com a população e seus representantes.

Há de se salientar, também, a importância dos projetos Rio Cidade a serem desenvolvidos por equipes interdisciplinares coordenadas por arquitetos, o que tem gerado soluções ricas $e$ integradas, particularmente no que diz respeito aos sistemas de circulação, o desenho viário e ao paisagismo. Neste sentido, a dificuldade maior, como já observamos, foi obter uma postura interdisciplinar por parte de alguns técnicos das concessionárias e da própria prefeitura, principalmente quando na resolução de questões com rebatimentos disciplinarmente mais amplos.

Finalmente, pode-se dizer que o balanço final do Projeto Rio Cidade é hoje bastante positivo, embora perante a opinião pública e durante o período inicial, ele fosse motivo de muita polêmica e constantes questionamentos, principalmente quanto ̀̀ real prioridade das obras e reclamações, principalmente quanto aos incômodos causados e aos impactos no difícil trânsito carioca. Entretanto, após as inaugurações, os usuários - moradores, comerciantes e transeuntes - passaram a ter uma avaliação bastante positiva dos resultados. Particularmente interessante é constatar o renascimento da importância da temática "urbanismo" junto à opinião pública e notar leigos trocando opiniōes sobre as soluções adotadas nas diferentes áreas de projeto. Além disto, em todas as áreas de projeto, têm-se verificado a valorização dos imóveis e dos pontos comerciais, por conta do aumento da qualidade do espaço público em geral, particularmente da segurança e do maior conforto no uso das calçadas.

Certamente, o Rio Cidade é um programa acertado, tanto em sua metodologia quanto em seu alcance, principalmente se compreendido dentro do contexto de desenvolvimento urbano carioca e como uma das peças do plano estratégico da cidade. A população pôde, efetivamente, apropriar-se melhor dos espaços públicos, sente-se novamente cuidada pelos governantes e, acima de tudo, a imagem da cidade está começando a mudar para melhor, nacional e internacionalmente. Assim, podemos sugerir que os três grandes avanços promovidos pelo Rio Cidade como sendo: a) o reconhecimento do papel do espaço urbano na vida carioca e para o lazer e a socialização de muitos grupos da população, particularmente nos bairros da zona norte; bl o destaque a eixos comerciais, que passam a assumir uma forte centralidade múltipla, no imaginário coletivo, em sua funcionalidade ou em sua capacidade de socialização; c) a importância da requalificação urbanística para a reconstrução da força dos lugares, a recuperação imagética da cidade e a atração de investimentos. 


\section{Bibliografia}

ABREU, Maurício de A. Evolução urbana do Rio de Janeiro. Rio de Janeiro: IPLANRIO/Zahar, 1987.

DEL RIO, Vicente, et al. Nascimento e apogeu do Shopping Center. Revista Módulo, n. 94, 1987.

DEL RIO, Vicente. Introdução ao desenho urbano no processo de planejamento. São Paulo: Pini, 1990.

. Reconquistando a imagem urbana e o espaço dos pedestres: Projeto Rio Cidade Méier.

In: VI ENCONTRO NACIONAL DA ANPUR. 1995, Brasília. Anais. Brasília: Associação Nacional de Pós-Graduação e Pesquisa em Planejamento Urbano e Regional, 1995.

RIO DE JANEIRO (cidade). Plano estratégico da cidade do Rio de Janeiro. Relatório da Cidade 2. Rio de Janeiro: Prefeitura da cidade do Rio de Janeiro, outubro 1996.

Rio Cidade: O urbanismo de volta às ruas. Rio de Janeiro: Prefeitura/IPLANRIO/Editora Mauad, 1997.

PINHEIRO, Augusto Ivan de Freitas. Corredor cultural, um projeto de preservação para o centro do Rio de Janeiro. In: TURKIENICZ, B., MALTA, M. Desenho Urbano, II SEDUR. São Paulo. Anais, São Paulo: CNPq/Finep/ Pini, 1986.

RIOARTE/IPLANRIO. Corredor CuItural: Como recuperar, reformar ou construir seu imóvel. Rio de Janeiro: Prefeitura da Cidade do Rio de Janeiro, 1985. 